SHEs: Conference Series 3 (3) (2020) $296-302$

\title{
The Use of Series Image Media to Improve the Ability to Write Non-Fiction Text
}

\author{
Fatma Risdiyati
}

SD Negeri 2 Bodaskarangjati

fatmaries86@gmail.com

\section{Article History}

accepted $01 / 11 / 2020 \quad$ approved $08 / 11 / 2020$ published $15 / 11 / 2020$

\begin{abstract}
The purpose of this research is to improve the ability to write non-fiction texts. This research is a classroom action research (PTK) which is conducted in three cycles, each cycle consisting of planning, implementation, observation, and reflection stages. The subjects of this study were the fifth grade students of SD Negeri 2 Bodaskarangjati for the 2020/2021 academic year, totaling 15 students. Data collection techniques using observation, interviews, data analysis, and tests. The data analysis technique used in this study is a comparative descriptive analysis technique, which is to compare the results of each cycle's actions with the predetermined work indicators. Interactive analysis is the interaction of the four components developed by Milles and Huberman (in H.B Sutopo, 2002: 96). The four components are 1) data collection, 2) data reduction, 3) data presentation in an effort to display data clearly and easily understood in narrative exposure, graphics, or other forms, and 4) drawing conclusions. Research shows that the use of serial image media can improve the ability to write non-fiction text in class V SD Negeri 2 Bodaskarangjati in the 2020/2021 school year as evidenced by the percentage of completeness of learning outcomes in cycle I by $40 \%$ to $93 \%$ in cycle III.

Keywords: Series Image Media, Writing, Non-fiction Text
\end{abstract}

\begin{abstract}
Abstrak
Tujuan penelitian ini adalah meningkatkan kemampuan menulis teks non fiksi. Penelitian ini merupakan penelitian tindakan kelas (PTK) yang dilaksanakan dalam tiga siklus, setiap siklus terdiri dari tahap perencanaan, pelaksanaan, observasi, dan refleksi. Subjek penelitian ini adalah peserta didik kelas V SD Negeri 2 Bodaskarangjati tahun pelajaran 2020/2021 yang berjumlah 15 peserta didik. Teknik pengumpulan data menggunakan observasi, wawancara, analisis data, dan tes. Teknik analisis data yang digunakan dalam penelitian ini adalah teknik analisis deskriptif komparatif, yaitu membandingkan hasil tindakan tiap siklus dengan indikator kerja yang telah ditetapkan. Analisis interaktif merupakan interaksi dari empat komponen yang dikembangkan oleh Milles dan Huberman (dalam H.B Sutopo, 2002: 96). Empat komponen tersebut adalah 1) pengumpulan data, 2) reduksi data, 3) pemaparan data upaya menmpilkan data secara jelas dan mudah dipahami dalam paparan naratif, grafik, atau bentuk lainnya, dan 4) penarikan simpulan. Penelitian menunjukkan bahwa penggunaan media gambar seri dapat meningkatkan kemampuan menulis teks non fiksi di kelas V SD Negeri 2 Bodaskarangjati tahun pelajaran 2020/2021 yang dibuktikan dengan persentase ketuntasan hasil belajar pada siklus I sebesar $40 \%$ menjadi $93 \%$ pada siklus III.
\end{abstract}

Kata kunci: Media Gambar Seri, Menulis, Teks Non fiksi

Social, Humanities, and Education Studies (SHEs): Conference Series p-ISSN 2620-9284 https://jurnal.uns.ac.id/shes e-ISSN 2620-9292 
SHEs: Conference Series 3 (3) (2020) $296-302$

\section{PENDAHULUAN}

Bahasa memiliki peran sentral dalam perkembangan intelektual, sosial, dan emosional peserta didik dan merupakan penunjang keberhasilan dalam mempelajari semua bidang studi. Pembelajaran bahasa diharapkan membantu peserta didik mengenal dirinya, budayanya, dan budaya orang lain, mengemukakan gagasan dan perasaan, berpartisipasi dalam masyarakat yang menggunakan bahasa tersebut dan menemukan serta menggunakan kemampuan analitis dan imaginatif yang ada dalam dirinya.

Pembelajaran Bahasa Indonesia diarahkan untuk meningkatkan kemampuan peserta didik untuk berkomunikasi dalam bahasa Indonesia dengan baik dan benar, baik secara lisan maupun tulis, serta menumbuhkan apresiasi hasil karya kesastraan manusia Indonesia.

Menulis merupakan aspek berbahasa yang tidak dapat dipisahkan dari aspek lain dalam poses belajar yang dialami peserta didik selama menuntut ilmu disekolah. Dalam kegiatan menulis, seorang penulis harus terampil memanfaatkan grafologi, struktur bahasa, dan kosakata. Dari pernyataan itu, dapat diketahui bahwa menulis merupakan suatu kemampuan berbahasa yang melibatkan berbagai keterampilan. Hal tersebut dapat dikatakan demikian karena menulis merupakan keterampilan yang memerlukan latihan-latihan yang berkelanjutan dan terus-menerus.

Keterampilan menulis oleh para ahli pengajaran bahasa ditempatkan pada tataran paling tinggi dalam proses pemerolehan bahasa. Hal ini disebabkan keterampilan menulis merupakan keterampilan produktif yang hanya dapat diperoleh sesudah keterampilan menyimak, berbicara, dan membaca. Hal ini pula yang menyebabkan keterampilan menulis merupakan keterampilan berbahasa yang dianggap paling sulit. Ketrampilan menulis merupakan keterampilan yang sangat penting dalam kehidupan, tidak hanya penting dalam kehidupan pendidikan, tetapi juga sangat penting dalam kehidupan masyarakat. Keterampilan menulis itu sangat penting karena merupakan salah satu keterampilan berbahasa yang harus dimiliki oleh seorang peserta didik.

Tujuan yang diharapkan dalam pembelajaran menulis adalah agar peserta didik mampu mengungkapkan gagasan, pendapat, dan pengetahuan secara tertulis, serta memiliki kegemaran menulis. Dengan keterampilan tersebut, peserta didik akan dapat mengembangkan kreativitasnya dan juga dapat menggunakannya sebagai sarana yang berharga dalam berbagai cara untuk belajar. Selain itu, keterampilan menulis berguna juga bagi peserta didik untuk menggali informasi baru, yang mereka dapatkan dengan baik dan mengintegrasikan dengan pengetahuan yang telah dimiliki (skemata) peserta didik.

Menulis merupakan suatu keterampilan berbahasa yang dipergunakan untuk berkomunikasi secara tidak langsung, tidak secara tatap muka dengan orang lain. Menulis merupakan suatu kegiatan yang produktif dan ekspresif.

Peserta didik untuk dapat menulis memerlukan suatu proses, tidak datang dengan sendirinya tetap memerlukan latihan. Akan tetapi pada kenyataannya menulis kurang disenangi peserta didik atau kurang diperhatikan peserta didik, sehingga peserta didik mendapatkan nilai rendah saat kemampuan menulis.

Rendahnya nilai peserta didik pada kemampuan menulis teks nonfiksi yang dialami oleh peserta didik kelas V SDN 2 Bodaskarangjati dikarenakan, terbatasnya kemampuan peserta didik dalam menyesuaikan antara judul dengan isi paragraf, penggunaan kosa kata yang belum maksimal, penggunaan ejaan dan tanda baca yang masih salah, terbatasnya kemampuan peserta didik dalam mengembangkan gagasan atau ide menjadi suatu bentuk karangan, terbatasnya kemampuan peserta didik dalam berimajinasi dan memberi kesan hidup pada objek karangan. Selain itu, peserta didik juga belum bisa memaksimalkan penginderaan dalam menulis paragraph. Dan faktor yang paling tampak adalah masih digunakannya pembelajaran konvensional oleh guru 
SHEs: Conference Series 3 (3) (2020) $296-302$

yakni mengajar peserta didik secara langsung dengan memberikan judul, tema, atau topik tertentu. Keadaan ini mengakibatkan tidak efektifnya pembelajaran menulis di kelas dan membuat para peserta didik bosan dan jenuh dalam menerima materi pelajaran.

Di SDN 2 Bodaskarangjati ditemukan kemampuan menulis peserta didik untuk menulis teks non fiksi rendah dapat dilihat dari hasil karya peserta didik yang dihasilkan. Dari 15 peserta didik, hanya 5 peserta didik yang tuntas belajar (33\%) dalam menulis teks non fiksi. Agar dapat menulis teks non fiksi sesuai yang diharapkan maka diperlukan suatu media dan metode yang tepat dalam proses pembelajaran sehingga dapat mengurangi kebosanan dan kejenuhan para peserta didik saat proses pembelajaran dan peserta didik lebih memahami dalam pembuatan teks non fiksi. Peneliti menggunakan media gambar berseri pada materi pelajaran menulis teks non fiksi.

Berdasarkan latar belakang masalah di atas, maka peneliti merumuskan masalah sebagai berikut: 1) Bagaimanakah penggunaan media gambar seri untuk meningkatkan kemampuan menulis teks non fiksi?; 2) Bagaimanakah penggunaan media gambar seri untuk meningkatkan kualitas proses pembelajaran menulis teks non fiksi?

Berdasarkan perumusan masalah tersebut, tujuan penelitian ini adalah sebagai berikut: 1) Penggunaan media gambar seri untuk meningkatkan kemampuan menulis teks non fiksi pada peserta didik kelas V SDN 2 Bodaskarangjati; 2) Penggunaan media gambar seri untuk meningkatkan kualitas proses pembelajaran menulis teks non fiksi pada peserta didik kelas V SDN 2 Bodaskarangjati

\section{METODE}

Penelitian ini merupakan penelitian tindakan kelas (PTK) kolaboratif yang dilaksanakan dalam tiga siklus, setiap siklus terdiri dari tahap perencanaan, pelaksanaan, observasi, dan refleksi. Subjek penelitian ini adalah peserta didik kelas $\mathrm{V}$ SD Negeri 2 Bodaskarangjati Tahun pelajaran 2020/2021 yang berjumlah 15 peserta didik. Data yang dianalisis berupa data kualitatif yaitu penggunaan media gambar seri dan data kuantitatif yaitu kemampuan menulis teks non fiksi. Teknik pengumpulan data menggunakan observasi, wawancara, tes, dan analisis dokumen. Uji validitas data menggunakan triangulasi metode dan review informan. Analisis data meliputi pengumpulan data, reduksi data, pemaparan data upaya menmpilkan data secara jelas dan mudah dipahami dalam paparan naratif, grafik, atau bentuk lainnya, dan penarikan simpulan.

\section{HASIL DAN PEMBAHASAN}

Berdasarkan analisis hasil penelitian yang telah diuraikan maka pembahasan pada penelitian ini sebagai berikut.

1. Hasil Analisis Observasi Aktivitas Guru dan Peserta Didik

Tabel 1. Hasil Analisis Observasi Aktivitas Guru dan Peserta Didik Siklus III

\begin{tabular}{lllcll}
\hline No & Aspek yang diamati & \multicolumn{5}{c}{ Skor } \\
& 1 & 2 & 3 & 4 & 5
\end{tabular}

Aktivitas guru

A 1. Menghubungkan pengalaman membaca peserta didik dengan materi

2. Memberikan pengalaman baru untuk peserta didik dengan memberikan contoh teks non fiksi 
SHEs: Conference Series 3 (3) (2020) 296 - 302

\section{Menyampaikan materi pembelajaran dengan baik dan mudah dipahami peserta didik. \\ 4. Memberikan kesempatan peserta didik untuk bertanya.}

5. Melakukan refleksi pada akhir pembelajaran

Aktivitas Peserta didik

B 1. Peserta didik siap mengikuti pembelajaran

2. Peserta didik aktif mengikuti pembelajaran

3. Peserta didik memperhatikan penjelasan guru.

4. Peserta didik mengerjakan tugas yang diberikan.

5. Peserta didik melakukan diskusi kelompok.

6. Peserta didik membuat teks non fiksi

Berdasarkan tabel 4.6 diperoleh keterangan bahwa pada aktivitas guru dalam pembelajaran sudah baik, dalam memberikan pengalaman membaca peserta didik dengan materi dan menyampaikan materi pembelajaran sudah sepenuhnya dipahami peserta didik sehingga banyak peserta didik memahaminya. Sedangkan aktivitas peserta didik sudah lebih baik dari siklus kedua yaitu dalam mengikuti pelajaran, memperhatikan pelajaran, mengerjakan tugas, diskusi kelompok dan membuat teks non fiksi.

2. Nilai Tes Formatif Peserta didik SDN 2 Bodaskarangjati Muatan Pelajaran Bahasa Indonesia dalam pembuatan teks non fiksi pada Siklus I, Siklus II, dan Siklus III

\begin{tabular}{|c|c|c|c|c|c|c|c|c|}
\hline \multirow{2}{*}{ No } & \multirow{2}{*}{ Nama Peserta didik } & \multirow{2}{*}{$\begin{array}{l}\text { Studi } \\
\text { Awal }\end{array}$} & \multirow{2}{*}{ Siklus I } & \multirow{2}{*}{$\begin{array}{c}\text { Siklus } \\
\text { II }\end{array}$} & \multirow{2}{*}{$\begin{array}{c}\text { Sikl } \\
\text { us } \\
\text { III }\end{array}$} & \multicolumn{2}{|c|}{ Kenaikan } & \multirow[t]{2}{*}{ Ketuntasan } \\
\hline & & & & & & Ada & Tidak & \\
\hline 1 & Alena Diah P & 50 & 50 & 75 & 75 & & $\sqrt{ }$ & $\mathrm{T}$ \\
\hline 2 & April Yoga Utomo & 30 & 40 & 60 & 70 & $\sqrt{ }$ & & $\mathrm{T}$ \\
\hline 3 & Candra Adi Saputra & 50 & 50 & 75 & 76 & $\sqrt{ }$ & & $\mathrm{T}$ \\
\hline 4 & Candra Tisahri & 50 & 60 & 75 & 78 & $\sqrt{ }$ & & $\mathrm{T}$ \\
\hline 5 & Cika Kurniawati & 80 & 90 & 92 & 93 & $\sqrt{ }$ & & $\mathrm{T}$ \\
\hline 6 & Elsa Bela & 50 & 80 & 90 & 90 & & $\sqrt{ }$ & $\mathrm{T}$ \\
\hline 7 & Farel & 50 & 60 & 72 & 73 & $\sqrt{ }$ & & $\mathrm{T}$ \\
\hline 8 & Junila Selfiana & 80 & 90 & 95 & 96 & $\sqrt{ }$ & & $\mathrm{T}$ \\
\hline 9 & $\begin{array}{l}\text { Lingga } \\
\text { Firmansyah }\end{array}$ & 80 & 90 & 95 & 96 & $\sqrt{ }$ & & $\mathrm{T}$ \\
\hline 10 & Mesi & 50 & 50 & 72 & 73 & $\sqrt{ }$ & & $\mathrm{T}$ \\
\hline
\end{tabular}


SHEs: Conference Series 3 (3) (2020) $296-302$

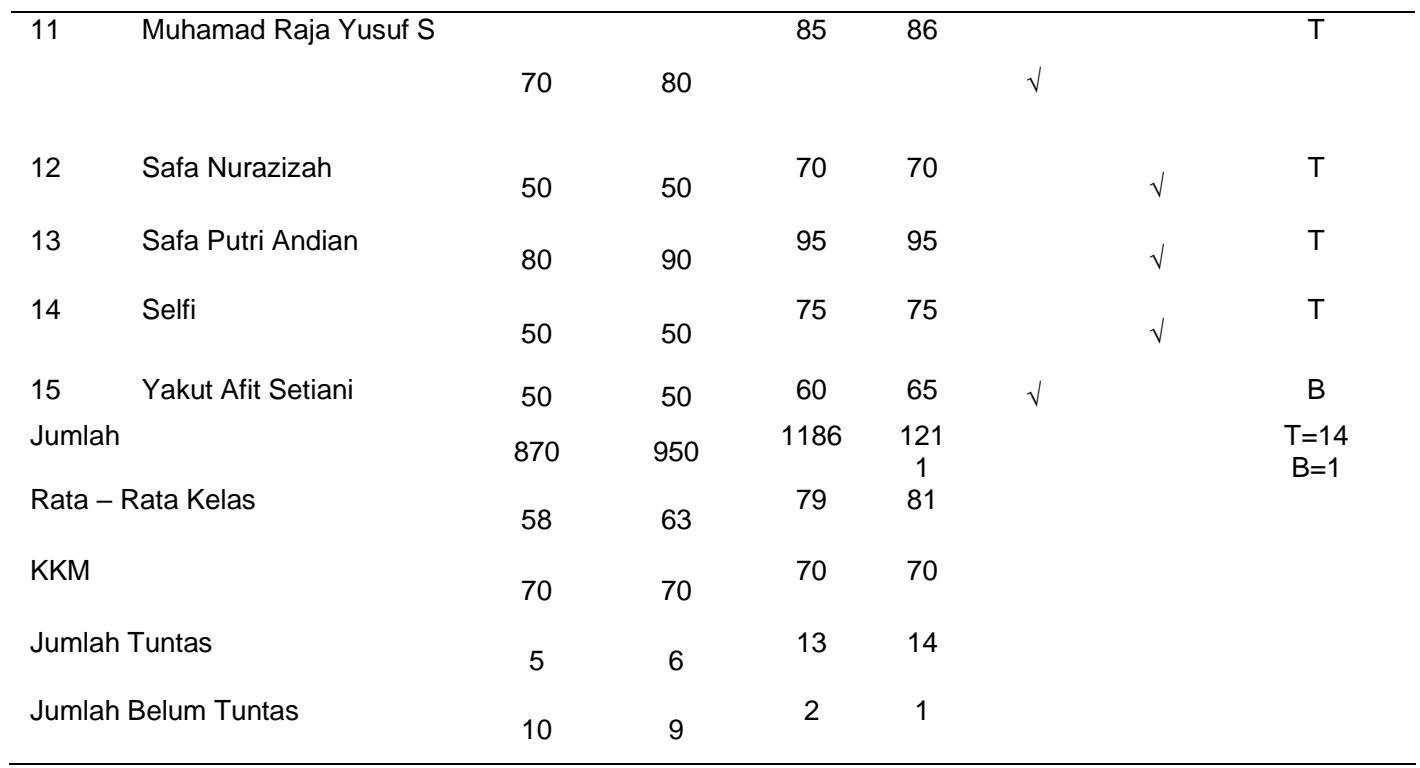

Berdasarkan pada tabel 4.7 diperoleh keterangan sebagai berikut:

1) Pada pembelajaran studi awal atau sebelum diadakan perbaikan banyaknya peserta didik yang tuntas ada 5 peserta didik atau 33\% dari 15 peserta didik dengan nilai rata-rata 58.

2) Pada pembelajaran siklus pertama setelah diadakan perbaikan banyaknya peserta didik yang tuntas belajar yaitu 6 peserta didik dari 15 jumlah keseluruhan atau presentasenya sebesar $40 \%$ dengan nilai rata-rata 63 .

3) Pada pembelajaran siklus kedua setelah diadakan perbaikan banyaknya peserta didik yang tuntas belajar yaitu 13 peserta didik dari 15 jumlah keseluruhan atau presentasenya sebesar $87 \%$ dengan nilai rata-rata 79 .

4) Pada pembelajaran siklus ketiga setelah diadakan perbaikan banyaknya peserta didik yang tuntas belajar yaitu 14 peserta didik dari 15 jumlah keseluruhan atau presentasenya sebesar $93 \%$ dengan nilai rata-rata 81 .

Sedangkan peserta didik yang belum tuntas belajar adalah sebagai berikut:

1) Pada studi awal, peserta didik yang belum tuntas belajar sebanyak 10 peserta didik dari 15 peserta didik (67\%).

2) Pada siklus I, peserta didik yang belum tuntas belajar sebanyak 9 peserta didik dari 15 peserta didik (60\%).

3) Pada siklus II, peserta didik yang belum tuntas belajar sebanyak 2 peserta didik dari 15 peserta didik (13\%).

4) Pada siklus III, peserta didik yang belum tuntas belajar sebanyak 1 peserta didik dari 15 peserta didik (7\%).

Untuk lebih jelasnya dapat kita perhatikan grafik berikut ini: 
SHEs: Conference Series 3 (3) (2020) $296-302$

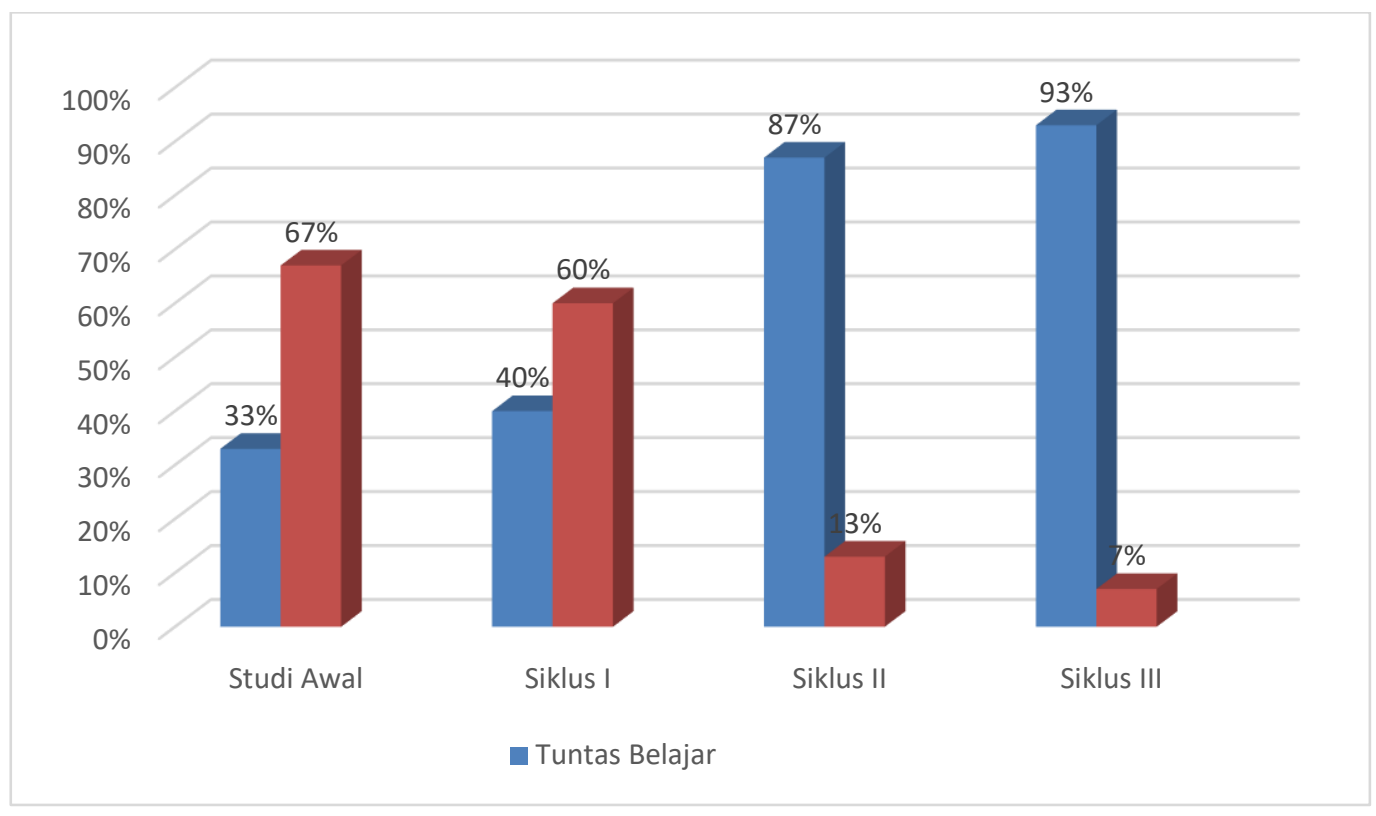

III :

Berikut tabel ketuntasan belajar peserta didik siklus I, siklus II, dan siklus

Tabel 3 Ketuntasan Belajar Peserta Didik pada Siklus I, Siklus II, dan Siklus III

\begin{tabular}{llcccc}
\hline No & $\begin{array}{c}\text { Kegiatan } \\
\text { Pembelajaran }\end{array}$ & $\begin{array}{c}\text { Peserta } \\
\text { yang tuntas } \\
\text { Jumlah }\end{array}$ & $\begin{array}{c}\text { Didik } \\
\%\end{array}$ & $\begin{array}{c}\text { Peserta } \\
\text { belum tuntas } \\
\text { Jumlah }\end{array}$ & yang \\
\hline 1 & Pra Siklus & 5 & 33 & 10 & 67 \\
2 & Siklus I & 6 & 40 & 9 & 60 \\
3 & Siklus II & 13 & 87 & 2 & 13 \\
4 & Siklus III & 14 & 93 & 1 & 7 \\
\hline
\end{tabular}

Pada pra siklus atau studi awal terdapat 5 peserta didik yang sudah tuntas belajar atau $33 \%$. Hal ini disebabkan guru belum menggunakan media dan metode pembelajaran yang menarik perhatian peserta didik. Pada siklus pertama, jumlah peserta didik yang yang sudah tuntas sebanyak 6 peserta didik atau $40 \%$. Guru sudah menggunakan media gambar seri. Pada siklus kedua, jumlah peserta didik yang yang sudah tuntas sebanyak 13 peserta didik atau $87 \%$. Guru sudah menggunakan media gambar seri. Pada siklus ketiga, jumlah peserta didik yang yang sudah tuntas sebanyak 14 peserta didik atau 93\%. Guru sudah menggunakan media gambar seri yang lebig beragam.

Ketuntasan belajar peserta didik dalam muatan pelajaran bahasa Indonesia dengan materi pokok teks non fiksi terlihat mengalami peningkatan dalam penguasaan materi yang signifikan. Penggunaan media gambar seri dalam menulis teks non fiksi dapat meningkatkan hasil belajar peserta didik yaitu 14 peserta didik dari 15 peserta didik sudah tuntas belajar atau 93\% dengan nilai rata-rata kelas 81 .

Berdasarkan uraian di atas dapat peneliti jelaskan bahwa ada peningkatan ratarata hasil belajar peserta didik dari siklus II ke siklus III. Hanya ada 1 peserta didik yang masih belum tuntas dan dapat diadakan remidi. 
SHEs: Conference Series 3 (3) (2020) $296-302$

\section{SIMPULAN}

Berdasarkan hasil penelitian dan uraian pembahasan maka dapat diambil simpulan bahwa penggunaan media gambar seri sebagai alat peraga untuk meningkatkan hasil belajar kelas V SD Negeri 2 Bodaskarangjati Tahun Pelajaran 2020/2021 meliputi langkah-langkah a) Menetapkan tujuan mengajar dengan menggunakan alat peraga, dalam hal ini merumuskan tujuan pembelajaran; b) Persiapan guru, pada fase ini guru memilih dan menerapkan alat peraga mana yang akan digunakan untuk mencapai tujuan pembelajaran; $\quad$ c) Persiapan kelas, peserta didik satu kelas harus mempunyai persiapan sebelum mereka menerima pelajaran dengan menggunakan alat peraga; d) Langkah penyajian pelajaran dan peragaan, guru harus memilih keahlian dan keterampilan yang baik dalam menggunakan alat peraga; e) Langkah kegiatan belajar, pada langkah ini hendaknya mengadakan kegiatan belajar sehubungan dengan menggunakan alat peraga.

Penggunaan media gambar seri dapat meningkatkan hasil belajar peserta didik kleas V SDN 2 Bodaskarangjati tahun pelajaran 2020/2021 dalam membuat teks non fiksi terbukti pada pembelajaran siklus pertama setelah diadakan perbaikan banyaknya peserta didik yang tuntas belajar yaitu 6 peserta didik dari 15 jumlah keseluruhan atau presentasenya sebesar $40 \%$. Pada pembelajaran siklus kedua setelah diadakan perbaikan banyaknya peserta didik yang tuntas belajar yaitu 14 peserta didik dari 15 jumlah keseluruhan atau presentasenya sebesar $93 \%$. Hanya terdapat 1 peserta didik yang belum tuntas sesuai KKM (70) maka diadakan remidi.

\section{DAFTAR PUSTAKA}

Arikunto, Suhardjono dan Supardi. 2006. Penelitian Tindakan Kelas. Jakarta: Bumi Aksara.

Aqib, Zainal, dkk. 2011. Penelitian Tindakan Kelas untuk Guru SD, SLB, dan TK. Bandung: Yrama Widya.

Daryanto. 2011. Media Pembelajaran. Bandung: PT. Sarana Tutorial Nurani Sejahtera.

Depdiknas. (2006). Standar Kompetensi Sekolah Dasar. Jakarta: Depdiknas

Henry Guntur Tarigan, Menulis (Bandung: Angkasa, 1982), HIm 3

Hermayana-hermayana.blogspot.co.id 4/05/2016 15:58

Hopkins, David. 1993. A Teacher's Guide to Classroom Research. Philadelphia: Open University Press.

Muclisah, Materi Pokok Bahasa Indonesia 3 (Jakarta: Universitas Terbuka, 1993), HIm 4

Mulyatiningsih, Endang. 2011. Metode Penelitian Terapan Bidang Pendidikan. Bandung: Alfabeta.

SPadmono, Y. 2010. Kekurangan dan kelebihan, Manfaat Penerapan PTK. Online: edukasi.kompasiana.com. 